\title{
SHARIAH DISCLOSURE EXPECTATION GAP BETWEEN SHARIAH PRACTITIONERS AND ISLAMIC BANKS' CUSTOMERS IN MALAYSIA
}

\author{
NUR AFIQAH MD AMIN 1 \\ NORAINI MOHD ARIFFIN 2,* \\ A.H. FATIMA ${ }^{2}$ \\ Received: 19 April 2020 / Revised: 15 December 2020 / Accepted: 30 December 2020 \\ (C) 2021 Faculty of Business and Accountancy, Universiti Malaya. All rights reserved.
}

\begin{abstract}
A B S T R A C T
Research aim: The aim of this study is to examine the possibility of a gap in perception between Shariah practitioners and customers of Islamic banks on the importance of Shariah disclosure by Islamic banks.

Design/ Methodology: Questionnaires were distributed to Shariah practitioners, consisting of Shariah committee members and Shariah officers, and Islamic banks' customers who were lecturers and final year accounting students. The concept of expectation gap derived from the auditing literature was extended and applied to this study's context. A total of 64 and 200 questionnaires were distributed to Shariah practitioners and customers of Islamic banks, respectively. The response rates were 41 per cent for Shariah practitioners and 65 per cent for Islamic banks' customers.
\end{abstract}

Research findings: The results indicate that Shariah practitioners and customers perceive all Shariah disclosure items as important to be disclosed. However, a few significant differences were noted between both groups, suggesting the existence of an expectation gap, albeit minimal. Only a minimal gap between the selected customers and practitioners may be reasonable, as the group of customers consisted of informed customers.

Theoretical contribution/ Originality: This study contributes to knowledge as there is a dearth of literature that determines customers' perceptions of Shariah disclosure.

Practitioner/ Policy Implications: The results provide regulators and Islamic banks with valuable insight into the importance of Shariah disclosure items from the points of view of customers and Shariah practitioners on which items they concur as important and which items they differ in opinion.

Limitation/ Implication: This study is an initial effort to examine the expectation gap between knowledgeable customers and Shariah practitioners on the Shariah disclosure made by Islamic banks. The customers are respondents from only one university; hence, there is a limitation concerning the generalisability of the findings. Thus, future research could extend such an investigation to other customers in order to enhance generalisability.

Keywords: Expectation Gap, Shariah Disclosure, Islamic Banks

Type of article: Research paper

JEL Classification: G21, M41, N25

\footnotetext{
${ }^{1}$ Yekon Equipment (M) Sdn Bhd, Kampung Subang Baru, 40150 Shah Alam, Selangor, Malaysia. ${ }^{2}$ Kulliyyah of Economics and Management Sciences, International Islamic University Malaysia, Kuala Lumpur 53100, Malaysia. ${ }^{*}$ Corresponding author, e-mail: norainima@iium.edu.my
} 


\section{Introduction}

Islamic banks are unique compared to conventional banks as all their operations and activities have to be Shariah compliant. In ensuring adherence to this fundamental rule, the regulatory authorities in Malaysia have strengthened the regulations pertaining to Shariah compliance by Islamic banks. Specifically, Bank Negara Malaysia (BNM) had produced guidelines in the form of a Shariah Governance Framework (SGF) in 2011. This SGF has since been superseded by the Shariah Governance Policy Document issued in 2019. In 2013, the Islamic Financial Services Act (IFSA) was enacted to licence and regulate Islamic banks. BNM has also issued guidelines on the Financial Reporting for Islamic Banking Institutions in 2019, which include disclosure on Islamic banks' compliance with the Shariah. All the disclosure items highlighted in the guidelines are mandatory to be disclosed by Islamic banks. Mandatory disclosure refers to information that is required to be disclosed by law and regulation. It is the minimum information that must be disclosed in the annual reports (Cooke, 1992). Every item in the guidelines is considered useful to the users of financial statements. Islamic banks are expected to disclose all the Shariah disclosure items highlighted in the guidelines due to the mandatory disclosure requirements. However, since the guidelines are relatively new, the extent of perceptions regarding the importance of the disclosure items, which are based on these mandatory guidelines, has not been examined.

Generally, Shariah practitioners would abide by these guidelines, and their perceptions of the importance of Shariah disclosure may be influenced by these regulations. However, problems may arise should customers have different expectations about what kind of Shariah information should be disclosed. Specifically, regulators may establish guidelines on Shariah disclosure by Islamic banks based on what is deemed important information for stakeholders. However, customers may not be aware of BNM's requirements, possibly giving rise to different opinions regarding what is important information to them. Therefore, an expectation gap may emerge between customers' demand and what Shariah practitioners perceive would be important for stakeholders in relation to Shariah disclosure. Hence, the aim of this study is to determine if there is a Shariah disclosure expectation gap between Shariah practitioners and the customers of Islamic banks in Malaysia. This paper defines "Shariah disclosure expectation gap" as the difference between customers' and Shariah practitioners' expectations on Shariah disclosure. The possible difference in expectation between these two groups is hypothesised in reference to the concept of expectation gap and theory of reasoned action. In this study, the Shariah practitioners consist of Shariah officers and committee members, whereas the customers are lecturers and Islamic accounting students who are currently customers of Islamic banks. 
Customers can be divided into two groups: those who are knowledgeable about the Shariah and reporting practices, and the layman. Regardless of whether a customer of an Islamic bank is knowledgeable or a layman, generally, a Muslim customer would be concerned about the practices within the Islamic banks and their compliance with the Shariah. However, a knowledgeable individual would have a better appreciation of the Shariah disclosure by Islamic banks in their annual reports. Therefore, this study focuses on customers' perception, specifically knowledgeable customers, on the importance of Shariah disclosure.

Islamic banks generally adhere to the Shariah disclosure guidelines in preparing their annual reports. In addition to the mandatory disclosure specified in these guidelines, Islamic banks are allowed to disclose voluntary information that they deem would be useful to their stakeholders in decision making. Given that Shariah practitioners are involved in the reporting process, it is necessary to evaluate whether what these practitioners consider as important Shariah disclosure is consistent with what customers perceive as important. This is because if these two groups' perceptions are inconsistent, there would be an expectation gap on Shariah disclosure. Consequently, even though Islamic banks incur a cost to disclose Shariah information as advised by their practitioners, this information would not be the one expected by the Islamic banks' customers. Hence, if the customers are dissatisfied with the information provided by an Islamic bank, particularly concerning Shariah disclosure, they may start losing confidence on whether that Islamic bank is indeed Shariah compliant in all its activities. Eventually, these dissatisfied customers may decide not to use that Islamic bank's services, leading to deposits withdrawals (Chapra \& Ahmed, 2002). Thus, logically, Shariah compliance is crucial to any Islamic institution, and their declaration to this commitment should be disclosed in their annual reports, or otherwise, these banks may start losing customers to competitors.

Although practitioners and customers may have wide-ranging perceptions as to the items that should be disclosed as part of Shariah disclosure, this study starts with their perceptions of the list of items required by the regulator (mandatory items), i.e., BNM. Some relevant items are also added based on the requirements of the Accounting and Auditing Organization for Islamic Financial Institutions (AAOIFI) (voluntary items). This is because even though Malaysian regulators do not require these items, such items are recommended by other authorities. Hence, this study examines the perceptions of these required and recommended items from the perspectives of Shariah practitioners and Islamic banks' customers.

Based on the above discussion, it is crucial to measure the expectation gap, in reference to theory of reasoned action, between Shariah practitioners and Islamic bank customers. This study's findings should be useful to Islamic banks 
because if there is any gap, the banks would want to know in which disclosure category or even in which specific disclosure item this gap exists. Only when the gap is discovered that the Islamic banks can work towards closing the expectation gap. Particularly, the banks could address the items that Islamic bank customers would like to see more in terms of Shariah disclosure.

On the other hand, if this study finds no or minimal expectation gap between Shariah practitioners and Islamic bank customers, then Islamic banks can be reassured. This is because these Islamic banks' Shariah practitioners would have a similar mindset with their customers; hence, the practitioners could advise the Islamic banks to report Shariah information that customers also perceive as important.

Given the intensifying competition in Islamic banking, it is vital that Islamic banks attract customers by disclosing information that is desired by their customers. All customers are important to the banks, more so knowledgeable customers because they should be better able to comprehend the disclosure in the annual reports. Moreover, relatives and friends could be seeking banking advice from these knowledgeable customers. Therefore, Islamic banks should be interested to know the information that knowledgeable customers deem important as they may be the ones conveying and relaying information to other customers.

In addition to the benefits of this research, as mentioned above, this study contributes by extending the existing literature. This is because prior studies have not considered the customers' perspective in terms of Shariah disclosure. This study not only includes customers' expectations but also calculates the gap between the expectations of customers and those of Shariah practitioners. Thus, in addition to the Islamic banks and regulators, the findings of this study could also be of interest to future researchers.

The next section reviews the relevant literature, followed by a discussion on theory, specifically theory of reasoned action, and hypothesis development. Then, the research method is described in the following section prior to the presentation of findings and discussion of results. Finally, the implications of the findings, limitations of the study, and suggestions for future research conclude this study.

\section{Literature Review}

Before moving into a discussion on the literature review, a brief background of Islamic banking in Malaysia is provided. Then, since this study is related to customers' perceptions and the expectation gap, the literature related to customers' perception of Islamic banks' services will be reviewed. Next, the expectation gap literature will be discussed prior to identifying the gap in the literature. 
The precursor of Islamic commercial banking in Malaysia is the Muslim Pilgrimage Saving Corporation (Lembaga Tabung Haji), established in 1963. This saving corporation safeguards Muslims' savings and invests the funds according to the Shariah law, whereby no riba (interest) is involved. Instead, annual dividends are paid out to depositors. Later, these depositors can use their savings to fund their pilgrimage. Two decades after the establishment of this saving corporation, the first full-fledged Islamic commercial bank in Malaysia, Bank Islam Malaysia Berhad (BIMB), was set up (Ariff, 1988). Since then, given the lucrative potential of the Islamic banking system, not only foreign full-fledged Islamic banks were established in Malaysia, but also conventional banks started offering Islamic products and services through Islamic windows. Gradually, these Islamic windows became established as subsidiaries of conventional banks. Currently, 16 commercial banks are offering Islamic banking services in Malaysia.

These Islamic banks were established on the basis that all their products, services, and operations are compliant with the Shariah. Following the establishment of the Islamic banks, there is a need to have financial reporting that adheres to the Shariah. One of the key components of Islamic banks' financial reports is the disclosure in relation to Shariah compliance. Other than BNM, which has issued Shariah disclosure guidelines, two standard setters at the international level have issued standards regarding the reporting practices of Islamic financial institutions. These organisations are the Accounting and Auditing Organization for Islamic Financial Institutions (AAOIFI) and the Islamic Financial Services Board (IFSB) (Sole, 2007). Although the AAOIFI standards are not adopted in Malaysia, AAOIFI is one of the earliest standard setters to issue accounting standards for Islamic financial institutions. Hence, AAOIFI standards could influence the voluntary reporting practices of Islamic banks in Malaysia. Similarly, the AAOIFI standards may influence Shariah practitioners or even Islamic banks' knowledgeable customers regarding their perception of the importance of Shariah disclosure.

Religious factors can influence the decision of individuals and society. For Muslims, Islam is a way of life, acting as a key force that influences the manner in which Muslims conduct their lives (Sulaiman, 2001). Customers' selection of Islamic banks has largely been studied, as evidenced in prior literature. The more a person believes in Islamic laws and fear divine punishment, the more favourable his/her attitude is towards Islamic banks (Souiden \& Rani, 2015). This notion infers that customers regard the Shariah aspect as important. However, Erol and Badour (1989) found that religious motives are not the only factor that encourages Jordanian depositors to use Islamic banking. Based on their survey of middle-class and middle-income households, professionals, merchants, and business concerns in the cities of Irbid, Zarka, and Amman, profit was an equally strong motivator. The justification is that since profit is 
not in conflict with Islamic legal doctrines, a fair return on investment is encouraged.

Similar to Erol and Badour (1989), Haron et al. (1994) found that it was not the religious factor that kept customers loyal to the Islamic banks in the northern states of Malaysia, but instead, the quality of service played a crucial role. Haque et al. (2009) confirmed the findings of Haron et al. (1994), as the latter study's results indicate a positive relationship between customers' perceptions about Islamic banks' quality of services and confidence in the banks. However, their findings also show that the religious perspective affects customers' perception and satisfaction towards Islamic banks. Echchabi and Olaniyi (2012) seem to integrate the findings of Haron et al. (1994) and Haque et al. (2009) finding. This is because based on the questionnaires distributed to 500 Islamic banks' customers in Malaysia, the customers' preference was for the quality of service, whereas the results of semi-structured interviews with 10 Islamic banks' customers revealed religious factor as the motivation.

In Malaysia, the literature may indicate that customers' preferences are divided between service quality and religious motivation, but this does not seem to be the case in other countries. Metawa and Almossawi (1998) conducted a study on the customers of Bahrain Islamic Bank and Faisal Islamic Bank. They found that religious factor has a high degree of importance in bank selection. Similarly, Saqib et al. (2016) investigated customers' perception regarding the Shariah compliance of Islamic banks in Pakistan compared to conventional banks. Their study revealed that customers' perception of Shariah compliance has a positive relationship with their satisfaction with Islamic banks.

In terms of specific studies on Shariah disclosure, Mat Nor and Md Sawari (2020) investigated Islamic banks' compliance in Malaysia in reporting nonShariah-compliant income in their annual reports. Their study found that a marginal majority (nine banks) fully complied, but the remainder of the Islamic banks needed to improve their disclosure of non-Shariah-compliant income. Meanwhile, other studies were conducted on the determinants of Shariah disclosure among Shariah-compliant companies in Kuwait (Al-Shammari, 2013) and Shariah financial institutions in Indonesia (Krismiaji \& Grediani, 2019). In both studies, organisation size was a positive determinant of Shariah disclosure, and in the latter, company age was also a positive determinant.

Subsequent to the literature review on customers' perception of Islamic banks, the following literature is on the expectation gap. Although the expectation gap literature started in the field of auditing, the literature has to be briefly reviewed as the current study proposes to test the expectation gap between the perception of customers and perception of Shariah practitioners regarding Shariah disclosure in the context of Islamic banks. 
The term expectation gap was first introduced by Liggio (1974) as the difference between the actual and expected performance of auditors. Then, the definition by Liggio (1974) was extended by the Cohen Commission (1978) as the gap between the expectation of users of financial statements and the performance of the auditor. Later, Monroe and Woodliff (1993) defined the expectation gap as the difference in perception between auditors and the public regarding auditors' responsibilities and duties. Generally, Monroe and Woodliff's (1993) definition of the expectation gap tends to be tested in the literature on audit expectation gap (Koh \& Woo, 1998).

About two decades after the term audit expectation gap was coined, the term expectation gap was extended into other research fields. For example, Trauth et al. (1993) investigated the expectation gap from the information systems (IS) industry's perspective, where they examined the difference between the IS industry's needs and graduate abilities. Similarly, Murphy and Maynard (1996) looked at the expectation difference in campaign values between advertising agencies and their clients. A study conducted by Douglas and Connor (2003) found a gap between managers' perceptions of consumers' expectations and actual customers' expectation of service quality.

Moreover, the expectation gap has also been tested in the aspect of reporting. Deegan and Rankin (1999) examined the perception difference between report users and preparers regarding the importance of environmental performance information in users' decision-making process. A total of 462 senior executives (preparers) of the largest companies in Australia and 474 various categories of annual report users were asked to fill up questionnaires to gather their perceptions of this matter. Similarly, Mitchell and Quinn (2005) surveyed the preparers of environmental reports (ERs) in South Africa (companies and professional environmental consultants) and selected users of ERs (environmental activists, pressure groups, and non-governmental organisation [NGOs] with environmentally related objectives). Both studies found the existence of a gap between the users and preparers.

In addition to environmental reporting studies, Chatterjee et al. (2017) conducted a study on infrastructure reporting by New Zealand local authorities. The study investigated the relationship between Annual Report Recipients' (ARR) information requirements and Infrastructure Information Preparers' (IIP) perception of the usefulness of infrastructure information items and disclosure such information. Similar to earlier studies on the expectation gap between users and preparers, Chartterjee et al. (2017) discovered an expectation gap between ARRs and IIPs in relation to infrastructure information reporting in the annual reports of New Zealand local authorities.

Other than studies on the expectation gap between users and preparers of annual reports, some studies investigated the gap between users' information expectations and the information actually disclosed in the annual reports. 
Among these studies are those conducted by Hooks et al. (2002) and KrambiaKapardis et al. (2016). The former identified stakeholders' expectation regarding the information that should be disclosed in the corporate annual reports of 33 integrated New Zealand electricity retail and distribution companies and then compared that with the actual disclosure in the annual reports. Meanwhile, Krambia-Kapardis et al. (2016) gathered users' expectation and the types of information included in public financial reports. Both studies discovered a gap between users' desired information and actual disclosure.

Based on the review of the literature above, there is a dearth of literature on the perception of Shariah reporting. In fact, studies on Shariah disclosure focus on disclosure or determinants of disclosure and not users' perception of this disclosure. Then, in relation to expectation gap studies, there seems to be a gap in the literature on the Shariah disclosure expectation gap. Hence, this study is warranted to fill this gap in the literature.

\section{Hypothesis Development}

This study's aim is to measure the expectation gap between Shariah practitioners and customers on Shariah disclosure. Although there is a dearth of prior studies on the expectation gap in relation to Shariah disclosure, the original expectation gap literature is in the field of audit; hence, the present study referred to this concept. The audit expectation gap concept specifically highlights the gap between preparers and users of financial statements regarding their perceptions of the duties and roles of auditors. This gap is explained by the difference in knowledge and experience between these two groups (Monroe \& Woodliff, 1993; Koh \& Woo, 1998; Fadzly \& Ahmad, 2004; Pourheydari \& Abousaiedi, 2011). In addition, all prior studies on expectation gap in reporting have proven the existence of a gap between the level of disclosure expected by customers or users of annual reports and practitioners' perception of the actual level of detail provided by the preparers of the annual reports (Deegan \& Rankins, 1999; Hooks et al., 2002; Mitchell \& Quinn, 2005; Chatterjee et al., 2017).

Although the expectation gap concept has been tested in numerous studies, it is not a theory. Hence, this study refers to theory of reasoned action, which provides an important framework and is extensively used by researchers in various fields of study such as psychology and management. Theory of reasoned action was formulated by Azjen and Fishbein $(1975,1980)$. Generally, this theory explains and predicts a wide range of human behavioural intention. Based on theory of reasoned action, an individual would be inclined towards a specific behaviour if the behaviour is perceived positively by the individual or influential others. Therefore, the perception of Shariah practitioners may influence the extent of Shariah reporting. When the Shariah practitioners perceive that the mandatory disclosure items are important, Islamic banks will 
disclose those items in the annual reports. The extent of Shariah disclosure by Islamic banks is based on Shariah practitioners' perception of Shariah disclosure.

Compared to Shariah practitioners, customers are less knowledgeable about the guidelines because customers have no actual practice on Shariah reporting. In fact, the present study used informed customers who have some knowledge of Islamic banking or Islamic transaction, but they are not practitioners in any of the Islamic banks. Customers might have a different expectation of Islamic banks, especially in terms of disclosure, in order for them to continue using Islamic banks' products. According to Sulaiman (2001), a Muslim's perception is influenced by the Islamic worldview, which is the Shariah. The greater the adherence of Islamic banks to the Shariah, the greater the possibility that an individual will use Islamic banking products. Thus, according to theory of reasoned action, customers' perception could also impact their action, i.e. the decision to deposit their money in certain Islamic banks over others. However, in accordance with the aim, this study does not test theory of reasoned action to the extent of respondents' action; instead, it measures perception and specifically tests the gap in perception, in line with the concept of expectation gap as per literature.

Extending the above concept to this study's context, this study anticipates a difference in perception between Shariah practitioners and customers. This is because both groups have different levels of knowledge and experience. The Shariah committee would either have the qualification or possess the necessary knowledge, expertise, or experience in Islamic jurisprudence and transactions (BNM, 2016). In fact, Shariah practitioners, who are Shariah officers and Shariah committee members, are the ones who are directly involved in Shariah reporting. Furthermore, compared to the customers, they are more aware and knowledgeable about the regulatory requirements on Shariah disclosure; hence, their perception may be influenced by their superior knowledge. Thus, based on theory of reasoned action, their perception of the importance of Shariah disclosure would affect Shariah reporting.

In contrast, generally, customers do not have experience in Shariah reporting. Moreover, although the groups of selected customers are knowledgeable customers, they still may not be updated about the latest regulation, and their perception may be based on theoretical knowledge instead of the practical perspective. More importantly, Shariah practitioners may have to consider Shariah disclosure in reference to all of the stakeholders of their Islamic bank, including the cost and benefit to the bank itself. On their side, customers would consider the importance of Shariah disclosure from their own perspective and the information that would be useful to them. Thus, based on theory of reasoned action, as well as extending the concept of expectation gap and the findings of previous studies, this study hypothesised that: There is 
a gap between Shariah practitioners' and customers' perceptions of Shariah disclosure.

\section{Research Method}

This study uses a quantitative research method. Primary data were collected because this study required the perceptions of Shariah disclosure from the perspectives of Shariah practitioners and customers of Islamic banks. Questionnaires were used instead of interviews due to the timeframe of the study, costs, and the available resources for data collection (Sekaran, 2010). Besides being cost-effective, questionnaires enable data collection from a large number of respondents in a short period of time. As a result, the findings can be generalised (Bryman \& Bell, 2003). In addition, a survey is an effective method to measure the respondents' perception (Cooper \& Schindler, 2011).

As for the sample selection, there are 16 banks providing Islamic banking services in Malaysia (BNM, 2016). Therefore, the target respondents of Shariah practitioners were the Shariah committee members of 16 Islamic banks in Malaysia and Shariah officers of these Islamic banks. Due to the small number of Shariah committee members in all the Islamic banks, the sample size consisted of the entire population. The list of the population of Shariah committee members as of 1 May 2017 was obtained from BNM. The number of Shariah committee members from all the Islamic banks in Malaysia is 83 members. These Shariah practitioners were contacted through electronic mail; however, only 46 members could be reached.

In order to increase the sample of Shariah practitioners, questionnaires were also distributed to 18 Shariah officers of Islamic banks during the $14^{\text {th }}$ Kuala Lumpur Islamic Finance Forum (KLIFF) 2017 event. Shariah officers are credible for this study because they are the ones who perform the Shariah review to ensure the activities and operation of Islamic banks are in line with the Shariah. To be a Shariah officer, they should have at least a bachelor's degree in Shariah, which includes courses in Usul Fiqh (the origin of Islamic Law) and Fiqh Muamalat (Islamic transaction) (SGF, 2011). The Shariah officers were selected through convenience sampling.

For each of the 16 Islamic banks, three to five questionnaires were distributed to Shariah practitioners, consisting of Shariah committee members and Shariah officers. Therefore, the total number of questionnaires distributed to Shariah practitioners is 64 .

As for the customers, this study used purposive sampling strategies to select the sample. The targeted customers consisted of lecturers and final year accounting students from a public university in Malaysia. The university was selected because most of the lecturers and students at that university were Muslims, and they had accounts in Islamic banks. Furthermore, these accounting students had to enrol in a number of Islamic-related courses in their 
accounting programme. One particularly relevant course was on Islamic accounting. The lecturers were from all departments in the Faculty of Economics and Management Sciences, and the Faculty of Law, specialising in Shariah. Thus, the lecturers and final year accounting students from this university were chosen as the targeted respondents (customers) because they are deemed to be informed or learned customers. An informed customer means that they would be more informed about Islamic banks as well as Islamic banks' transactions and reporting practices compared to the average layperson. Therefore, these respondents would be familiar with the terms used by Islamic banks such as gharamah (penalty) and t'awidh (compensation) charges. Hence, the questionnaires were distributed to 80 lecturers and 120 final year accounting students, i.e., 200 customers. It is crucial to attain the customers' perspective because depositors are the main fund contributors for Islamic banks instead of investors.

The questionnaires were developed by listing the items required in the Financial Reporting for Islamic Banking Institutions guidelines by BNM. There were 31 mandatory items, and five voluntary items were added from the AAOIFI standards. Hence, a total of 36 Shariah disclosure items were extracted from all the guidelines and then grouped into five categories: financing, deposit and investment, zakat and charity, non-Shariah-compliant activities, Shariah committee information, and Qard. The importance of the items in these five categories was queried in Section A of the questionnaire. The respondents were asked to determine the importance of each item based on their perception using a five-point Likert scale. The scale ranged from 1 (not important at all) to 5 (extremely important). At the end of Section A, an open-ended question was included for the respondents to propose other items that they considered important but were not on the list of 36 items. Then, the demographics of the respondents were asked in Section B of the questionnaire. The demographics required of the Shariah practitioners differed from those of the customers. The questions for the Shariah practitioners were to attain their qualification and work experience, whereas those for the customers were to ascertain that they were indeed customers of Islamic banks and whether they were lecturers or students.

The items in the questionnaire (as in Appendix) were chosen because these are the items required by BNM; Shariah practitioners should consider the items important as these are mandatory items. However, customers may lack awareness about these items, even though they are learned customers. Hence, the latter may have a different perception of the importance of these items, albeit these items are mandatory. In addition, a few items recommended by the AAOIFI were also included to determine the practitioners' and customers' perceptions of these items. Since this is not a disclosure study but a study on expectation gap, it was deemed necessary to test customers' perception of 
required and recommended disclosure to determine whether their perception was consistent with the practitioners' perception.

Prior to administering the questionnaire, a pilot test was performed to ensure the validity of the questionnaire (Saunders et al., 2009). The pilot questionnaires were distributed to 10 final year accounting students from the selected university and a Shariah committee member of an Islamic bank. The practitioner, i.e., the Shariah committee member, was willing to spend time to discuss and give in-depth suggestions on the questionnaire. Generally, the questions and instructions were understandable and clear. The respondents also believed that the questions met the objective of the study. Only the structure and a few words in the questionnaire had to be amended to enhance clarity. Improvements were made before producing the final questionnaire instrument.

In order to administer the survey, the questionnaire was designed using Google Forms. The Shariah practitioners were contacted through electronic mail and requested to fill in the form via a link that directed them to the form. However, the questionnaires to customers were self-administered. In either case, a cover letter was attached to the form to inform the respondents about the study, their anonymity, and the confidentiality of their responses.

Mainly rudimentary statistical techniques were needed to meet the objective of this study. A measure of central tendency, specifically mean values, was used to measure the respondents' perception regarding the importance of each of the Shariah items. Then, independent sample $t$-tests were used to measure the Shariah disclosure expectation gap between Shariah practitioners and Islamic banks' customers.

\section{Findings}

As shown in Table 1, all categories of Shariah disclosure were rated more favourably by customers than practitioners, as customers have higher minimum values. The customers also have higher or similar maximum values than the practitioners', except for financing, deposit, and investment categories where the practitioners' perceptions are marginally higher. However, the maximum value for the Shariah committee category is higher for the practitioners than the customers. These minimum and maximum values are reflected in the mean values as, on average, the disclosures on zakat and charity, non-Shariah-compliance activities, and Qard are deemed to be more important by the customers than the practitioners. On the other hand, disclosure on the Shariah committee is perceived to be more important by the practitioners than the customers. Besides, based on the mean values, both practitioners and customers perceive the financing, deposit, and investment categories as equally important. 
Table 1 Perception of Practitioners and Customers

\begin{tabular}{lccccccc}
\hline Category & \multicolumn{3}{c}{ Practitioners } & \multicolumn{3}{c}{ Customers } \\
\cline { 2 - 4 } & Min. & Max. & Mean & Min. & Max. & Mean \\
\hline Financing, Deposit and Investment & 3.88 & 4.54 & 4.25 & 4.07 & 4.53 & 4.25 \\
Zakat and Charity Fund & 3.81 & 4.54 & 4.22 & 4.29 & 4.64 & 4.47 \\
Non-Shariah Compliance Activities & 4.19 & 4.54 & 4.38 & 4.40 & 4.54 & 4.47 \\
Shariah Committee & 3.50 & 4.69 & 4.40 & 3.89 & 4.50 & 4.28 \\
Qard & 3.65 & 4.19 & 4.22 & 4.26 & 4.40 & 4.47 \\
\hline
\end{tabular}

Table 2 presents the expectation gap, which is the differences in the mean values between the two groups that enable further analysis of every item in each category. The table also shows whether the expectation gap for each item is significant. In analysing each of the items in the financing, deposit, and investment categories, none of the items is significantly different as their $p$ values are greater than 0.1 . This finding indicates that practitioners' and customers' perceptions are similar on all items in these categories, and there is no expectation gap between them concerning the importance of disclosure on financing, deposit, and investment.

Similarly, there is no expectation gap between practitioners and customers on all items in the zakat and charity category, except for three items. These items are disclosure of the zakat fund beneficiaries, disclosure of why Islamic banks do not pay zakat, and disclosure of the sources of donations or charities. In each case, the customers perceived the disclosure of these items as more important; the expectation gaps between the two groups for these three items are $0.64,0.75$, and 0.44 , respectively. The disclosures of beneficiaries of the zakat fund and reasons that Islamic banks do not pay zakat are significant at the 1 per cent significance level, whereas the disclosure of sources of donations and charities is significant at the 5 per cent significance level.

Regarding Shariah committee disclosure, Shariah committee members' signatures on the Shariah report are significantly deemed more important (at the $1 \%$ significance level) by the practitioners than the customers, with an expectation gap of 0.4 . Similarly, compared to the customers, the practitioners consider the Shariah committee's endorsement of Shariah compliance in contracts and documents as significantly (at the $1 \%$ significance level) more important, with an expectation gap of 0.36. However, all other items on the disclosure of the Shariah committee are perceived as equally important by practitioners and customers as the expectation gaps between the items are not significant.

Finally, for the three items in the Qard category, only one item is perceived as significantly more important by the customers compared to the practitioners. This item is on the Qard fund sources, where there is a significant expectation gap at the 1 per cent significance level. 
Table 2 Expectation Gap

\begin{tabular}{|c|c|c|c|}
\hline No. & Item & $\begin{array}{c}\text { Mean } \\
\text { diff. }\end{array}$ & $\begin{array}{l}\text { Sig. } \\
\text { value }\end{array}$ \\
\hline \multicolumn{4}{|c|}{ Financing, Deposit, and Investment } \\
\hline 1 & $\begin{array}{l}\text { Types of financing (home, personal financing, etc.) offered by the } \\
\text { bank }\end{array}$ & 0.01 & 0.983 \\
\hline 2 & $\begin{array}{l}\text { Classification of financing into main Shariah contracts (BBA, } \\
\text { murabahah, etc.) }\end{array}$ & 0.04 & 0.813 \\
\hline 3 & Ta'widh (compensation) charges for late payment financing & 0.16 & 0.399 \\
\hline 4 & Gharamah (penalty) charges for late payment financing & -0.24 & 0.244 \\
\hline 5 & Type of Islamic deposits (saving, demand, etc.) & -0.07 & 0.640 \\
\hline 6 & $\begin{array}{l}\text { Classification of Islamic deposits into main Shariah contract } \\
\text { (wadi'ah, tawarruq) }\end{array}$ & 0.09 & 0.543 \\
\hline 7 & Opening and closing balance of restricted investment & 0.24 & 0.155 \\
\hline 8 & Sources of unrestricted investment account & -0.27 & 0.132 \\
\hline 9 & $\begin{array}{l}\text { Classification of unrestricted investment account into main } \\
\text { Shariah contract }\end{array}$ & 0 & 0.959 \\
\hline 10 & Profit sharing ratio of unrestricted investment account & 0.01 & 0.941 \\
\hline 11 & Method used to allocate investment profit (separate vs. pooling) & 0.03 & 0.873 \\
\hline \multicolumn{4}{|c|}{ Zakat and Charity Fund } \\
\hline 12 & Opening and closing balance of zakat fund & -0.02 & 0.878 \\
\hline 13 & Amount of zakat payable & 0.07 & 0.594 \\
\hline 14 & Amount of zakat distributed & -0.10 & 0.432 \\
\hline 15 & Bank's responsibility to pay zakat & -0.10 & 0.636 \\
\hline 16 & Method applied in determining zakat base & -0.05 & 0.762 \\
\hline 17 & Beneficiaries of zakat fund & -0.64 & $0.009^{* *}$ \\
\hline 18 & Reason for Islamic bank for not paying zakat & -0.75 & $0.005^{* *}$ \\
\hline 19 & Sources of donations/charities fund & -0.44 & $0.029^{*}$ \\
\hline 20 & Usage of donations/charities fund & -0.22 & 0.109 \\
\hline \multicolumn{4}{|c|}{ Non-Shariah Compliance Activities } \\
\hline 21 & Nature of non-Shariah compliance activity & -0.09 & 0.581 \\
\hline 22 & Amount of non-Shariah compliance income & -0.01 & 0.938 \\
\hline 23 & $\begin{array}{l}\text { Number of non-Shariah compliance activities which occurred } \\
\text { during the year }\end{array}$ & -0.24 & 0.152 \\
\hline 24 & Rectification process to avoid recurrence & -0.15 & 0.420 \\
\hline 25 & Control measure to avoid recurrence & -0.09 & 0.561 \\
\hline 26 & Disposal of prohibited earnings to charity causes & 0.01 & 0.933 \\
\hline \multicolumn{4}{|c|}{ Shariah Committee } \\
\hline 27 & $\begin{array}{l}\text { Shariah committee members' signature on Shariah committee } \\
\text { report }\end{array}$ & 0.40 & $0.001^{* *}$ \\
\hline 28 & Purpose of Shariah committee engagement & 0.31 & $0.042^{*}$ \\
\hline 29 & Nature of work performed by Shariah committee & 0.08 & 0.613 \\
\hline 30 & Management responsibility on ensuring Shariah compliance & 0.12 & 0.386 \\
\hline 31 & $\begin{array}{l}\text { Shariah committee endorsement on Shariah compliance in } \\
\text { contract and document }\end{array}$ & 0.36 & $0.007^{* *}$ \\
\hline 32 & Shariah committee member's remuneration & -0.39 & 0.125 \\
\hline 33 & Shariah committee member's qualification & -0.01 & 0.947 \\
\hline \multicolumn{4}{|c|}{ Qard } \\
\hline 34 & Opening and closing balance of qard & -0.07 & 0.772 \\
\hline 35 & Sources of qard fund & -0.75 & $0.004^{* *}$ \\
\hline 36 & Usage of qard fund & -0.38 & $0.023^{*}$ \\
\hline
\end{tabular}

Note: ${ }^{* *}$ significant at $1 \%$ significance level; ${ }^{*}$ significant at $5 \%$ significance level 
On average, the results show that Shariah practitioners perceive all items as important to be disclosed in the annual reports. Such findings are consistent with theory of reasoned action; since practitioners are knowledgeable about the regulatory requirements, they would perceive these items to be important, and consequently, these practitioners would ensure that the Islamic banks disclose these items.

In terms of customers' perception, the main findings show that the customers believe all items as important to be disclosed. Based on the studies by Metawa and Almossawi (1998), Echchabi and Olaniyi (2012), and Saqib et al. (2016), since Shariah customers' compliance perceptions influence their attitudes towards Islamic banks, they, therefore, demand more disclosure in terms of Shariah-related items in deciding whether to deal with Islamic banks. Therefore, Islamic banks or regulators should ensure that the necessary Shariah disclosure is performed to satisfy customers' needs.

There are some differences between Shariah practitioners and customers in terms of their perceptions of Shariah disclosure. The independent sample $t$-test shows that only 22 per cent of the items have a significant difference in terms of perception. Among them, several items are perceived as more important by the customers than by the Shariah practitioners, such as the disclosure of zakat fund beneficiaries and the disclosure of donation fund sources. Therefore, banks consider disclosing those items, especially if they intend to attract more customers. This is because those items are valued highly by customers, signifying their concern about the social aspects. In addition, a few items related to governance are valued more by the Shariah practitioners, such as Shariah committee members' signatures on the Shariah committee report and the purpose of Shariah committee engagement. This is because Shariah committee members are directly involved in the Shariah governance structure of Islamic banks. Customers consider governance as important because if any breach occurs, it could be detrimental to the reputation of Islamic banks.

The remaining 78 per cent of the items show no significant difference between the two groups. As discussed earlier, this might be due to similar levels of understanding of the issues. Therefore, their perceptions do not differ much. However, these findings could be tested further in future studies that extend the sample frame to wider customer groups.

The interesting finding is, both groups have similar perceptions regarding the five voluntary items, namely the opening and closing balances of restricted investments, sources of unrestricted investment accounts, profit sharing ratios of unrestricted investment accounts, the method used to allocate investment profits, and the opening and closing balances of the zakat fund. Both groups think that it is important to disclose those items. Therefore, these findings suggest that regulators should consider incorporating the voluntary items into the guidelines to ensure that customers are satisfied with the Shariah 
information provided by banks besides being reassured about banks' Shariah compliance. These factors are important to ensure that they will continue to keep their savings in the Islamic banks. Such actions are indicative of theory of reasoned action because if customers perceive Islamic banks' Shariah compliance positively, they will continue to patronise these banks.

Based on the above findings, there seems to be a minimal expectation gap between practitioners and customers of Islamic banks; thus, in reference to the majority of the Shariah disclosure items, the hypothesis in this study: There is a gap between Shariah practitioners' and customers' perceptions of Shariah disclosure is not supported. Nevertheless, there are a few items in three categories that show a significant expectation gap between the two groups. The implications of these findings will be deliberated in the next section.

\section{Conclusion}

This study's aim is to determine whether an expectation gap exists between practitioners and customers of Islamic banks on the Shariah disclosure of these banks. The findings revealed that the expectation gap exists for only a few items. This seems to be good news for banks, as generally, items deemed important by practitioners are also deemed important by banks' customers. In addition to regulation, practitioners working with Islamic banks are likely to influence these banks' disclosure practices. Hence, if Shariah disclosure items are perceived as important by practitioners, based on theory of reasoned action the Islamic banks would disclose these items under the influence of the practitioners who are Shariah committee members and Shariah officers. Since customers perceive the same items as important, Islamic banks would benefit as generally, they would be disclosing the items that the customers want to be disclosed. Therefore, action based on perception is consistent with theory of reasoned action. In addition, this study contributes to knowledge as there is a dearth of literature that determines customers' perception of Shariah disclosure.

Although practitioners and customers are in agreement on most items, it has to be noted that social welfare is perceived as more important by customers than by practitioners. These items are sources of donations and Qard, as well as beneficiaries of zakat. The customers also perceive that Islamic banks must be transparent about their reasons for not paying zakat. These findings are useful to Islamic banks as they indicate that banks' customers value transparency on social welfare issues. Hence, it is pertinent that Islamic banks do not underestimate the importance of these disclosure items to their customers if they want to maintain or even grow their customer base. In contrast, the practitioners revealed the gravity of the Shariah committee's responsibility regarding their commitment to endorsing Shariah-compliant transactions and products, hence the significance of the committee members' signatures on the 
Shariah Committee report. These findings can provide an assurance to the customers of Islamic banks that practitioners do indeed take their responsibilities seriously and are aware of their accountability to the banks' stakeholders.

Furthermore, this study's findings may also be of interest to BNM as the Shariah disclosure required by this regulator is also agreed upon by the key stakeholders of Islamic banks, i.e., the customers. At least, BNM can be reassured that knowledgeable customers support the disclosure of the items prescribed by BNM, as they too perceive these items to be important. Thus, the results of this study provide supporting evidence that BNM does not require disclosure from Islamic banks for its own sake; rather, this information is also sought by Islamic banks' key fund contributors.

Despite the merits of the above findings, there are a few notable limitations to this study. First, it has to be noted that the customer group only consists of knowledgeable customers who are aware of the Shariah disclosure practices of Islamic banks. Therefore, it is logical that knowledgeable customers' perceptions would generally be congruent with practitioners' perceptions. Hence, future studies should include other customers' perceptions in order to determine the expectation gap between them and practitioners. Due to their busy schedule, the response rate of Shariah practitioners was considerably lower than that of customers. Although ample, future research could consider carrying out semi-structured interviews to possibly enhance the response rate of practitioners.

This study only measured the expectation gap in accordance with its objective. It did not proceed to interview practitioners or customers to determine the possible reasons for this gap. Therefore, future studies could investigate further by using qualitative data to complement and extend the findings from the quantitative data of this study. While this study may be considered as relatively simple, it has some worthwhile findings that could be of interest to regulators, customers, and Islamic banks themselves. This study could also be easily replicated the context of Islamic banks in other countries to compare the findings across countries. It is hoped that this study would inspire future similar research on the Islamic banks of other countries.

\section{Acknowledgment}

This research was funded by the Malaysian Ministry of Higher Education under Fundamental Research Grant Scheme (FRGS). (Grant number: FRGS/1/2015/SS01/UIAM/02/7). 


\section{References}

Accounting and Auditing Organization for Islamic Financial Institutions (AAOIFI) (1991). Shariah standard. Retrieved from https://www.iasplus.com/en/resources/topics/islamic-accounting

Al-Shammari, B. A. (2013). An investigation of the determinants of voluntary disclosure by Kuwaiti Shariah-compliant companies. Arab-Journal of Administrative Sciences, 20(1), 85123.

Ariff, M. (1988). Islamic banking. Asian-Pacific Economic Literature, 2(2), 46-62.

Bank Negara Malaysia (2016), Banking and Islamic banking. Retrieved from https://www.bnm.gov.my/banking-islamic-banking

Bank Negara Malaysia (2016), List of Licensed Financial Institutions in Malaysia. Retrieved from https:/ / www.bnm.gov.my/list-of-licensed-financial-institutions

Bank Negara Malaysia (BNM). (2016). Financial Reporting for Islamic Banking Institutions (GP8i). Kuala Lumpur: Bank Negara Malaysia.

Bryman, A., \& Bell, E. (2003). Breaking down the quantitative/qualitative divide. In Business Research Methods (pp. 465-478). Oxford University Press.

Chapra, M. U., \& Ahmed, H. (2002). Corporate Governance in IFIs. Islamic Development Bank, Islamic Research and Training Institute, Periodical Document, (6).

Chatterjee, B., Mir, M. Z., Eddie, I. A. \& Wise, V. (2017). Infrastructure reporting by New Zealand local authorities-perceptions and expectations. Accounting Research Journal, 30(1), 36-57.

Commission on Auditor's Responsibilities (Cohen Commission) (1978). Report, Conclusions and Recommendations, American Institute of Certificate Public Accountants, New York, NY.

Cooper, D. R. \& Schindler, P. S. (2011). Business research methods (11th ed). New York: McGrawHill Irwin.

Deegan, C. \& Rankin, M. (1999). The environmental reporting expectation gap: Australian evidence. British Accounting Review, 31(3), 313-346. https://doi.org/10.1006/bare.1999.0102

DiGabriele, J. A. (2016). The expectation differences among stakeholders in the financial valuation fitness of auditors. Journal of Applied Accounting Research, 17(1), 43-60. https://doi.org/10.1108/JAAR-06-2013-0043

Douglas, L., \& Connor, R. (2003). Attitudes to service quality-the expectation gap. Nutrition and Food Science, 33(4), 165-172. https://doi.org/10.1108/00346650310488516

Echchabi, A., \& Olaniyi, O. N. (2012). Malaysian consumers' preferences for Islamic banking attributes. International Journal of Social Economics, 39(11), 859-874. https://doi.org/10.1108/03068291211263907

Erol, C. \& Badour, R. (1989). Attitudes, behaviour, and patronage factors of bank customers towards Islamic banks. International Journal of Bank Marketing, 7(6), 31-37. https:// doi.org/10.1108/02652328910132060

Fadzly, M. N. \& Ahmad, Z. (2004). Auditing expectation gap: the case of Malaysia. Managerial Auditing Journal, 19(7), 897-915. https:// doi.org/10.1108/02686900410549420

Frank, K. E., Lowe, D. J. \& Smith, J. K (2001). The expectation gap: perceptual differences between auditors, jurors, and students'. Managerial Auditing Journal, 16(3), 145-149. https:// doi.org/10.1108/02686900110385588

Haque, A. K. M., Osman, J., \& Ismail, A. Z. (2009). Factor influences selection of Islamic banking: a study on Malaysian customer preferences. American Journal of Applied Sciences, 6(5), 922-928. 
Haron, S., Ahmad, N. \& Planisek, S.L. (1994). Bank Patronage Factors of Muslim and NonMuslim Customers. International Journal of Bank Marketing, 12(1), 32-40. https:// doi.org/10.1108/02652329410049599

Hooks, J., Coy, D., \& Davey, H. (2002). The information gap in annual reports. Accounting, $\begin{array}{llll}\text { Auditing Accountability Journal, 15(4), 501-522. } & \end{array}$ https://doi.org/10.1108/09513570210440577

Islamic Financial Service Act 2013 (IFSA) (Malaysia).

Koh, H. C. \& Woo, E. S. (1998). The expectation gap in auditing. Managerial Auditing Journal, 13(3), 147-154. https:// doi.org/10.1108/02686909810208038

Krambia-Kapardis, M., Clark, C., \& Zopiatis, A. (2016). Satisfaction gap in public sector financial reporting. Journal of Accounting in Emerging Economies, 6(3), 232-253. https://doi.org/10.1108/JAEE-08-2013-0040

Krismiaji \& Grediani, E. (2019), Effects of company size, company age, audit committee, and auditor quality on Sharia information disclosure compliance: an Indonesian Sharia financial industry evidence, International Conference on Economics, Management and Accounting Volume 2019.

Liggio, C. D. (1974). The expectation gap: The accountant's legal Waterloo?. The CPA (pre1986), 45(7), 23.

Malaysian Accounting Standard Board (2011). The Conceptual Framework for Financial Reporting.

Retrieved

from https://www.masb.org.my/pdf.php?pdf=conceptual\%20framework\%20042015t.pdf\&fil e_path $=$ pdf

Malaysia International Islamic Financial Centre (2014). Shariah Compliance in All Matters. The Priority of a Robust Islamic Finance Ecosystem. Retrieved from http:/ / www.mifc.com/index.php?ch=28\&pg=72\&ac=67\&bb=uploadpdf

Mat Nor, N. \& Md Sawari, M. F. (2020). The practice of reporting Shariah non-compliant income in the annual financial report of Islamic commercial banks in Malaysia. Islamiyyat, 42(1), 93-102.

Metawa, S. A. \& Almossawi, M. (1998). Banking behavior of Islamic bank customers: perspectives and implications. International Journal of Bank Marketing, 16(7), 299-313. https://doi.org/10.1108/02652329810246028

Mitchell, C. G., \& Quinn, N. W. (2005). Environmental reporting disclosure in South Africa: A comparative study of the expectations of selected groups of preparers and users. Meditari Accountancy Research, 13(2), 17-33. https:// doi.org/10.1108/10222529200500010

Monroe, G. S., \& Woodliff, D. R. (1993). The effect of education on the audit expectation gap. Accounting and Finance, 33(1), 61-78. https:// doi.org/10.1111/j.1467-629X.1993.tb00195.x

Murphy, P. \& Maynard, M. L. (1996). Using judgement profiles to compare advertising agencies and clients campaign values. Journal of Advertising Research, 36(2), 19-27.

Onumah, J. M., Simpson, S. N. Y. \& Babonyire, A. (2009). The audit expectation gap concept: Examining views on auditors' reports from Ghana. In Tsamenyi, M., \& Uddin, S. (Eds.) Accounting in Emerging Economies (Research in Accounting in Emerging Economies, Vol. 9) (pp. 321-343). Emerald Group Publishing Limited. https://doi.org/10.1108/S1479$\underline{3563(2009) 0000009014}$

Porter, B., \& Gowthorpe, C. (2004). Audit expectation-performance gap in the United Kingdom in 1999 and comparison with the Gap in New Zealand in 1989 and in 1999. Edinburgh, Scotland: Institute of Chartered Accountants of Scotland.

Pourheydari, O., \& Abousaiedi, M. (2011). An empirical investigation of the audit expectations gap in Iran. Journal of Islamic Accounting and Business Research, 2(1), 63-76. https://doi.org/10.1108/17590811111129517

Quran 4:86, Oxford Worlds Classic edition 
Saqib, L., Farooq, M. A. \& Zafar, A. M. (2016). Customer perception regarding Sharīah compliance of Islamic banking sector of Pakistan. Journal of Islamic Accounting and Business Research, 7(4), 282-303 https:/ / doi.org/10.1108/JIABR-08-2013-0031

Saunders, M., Lewis, P. \& Thornhill, A. (2009). Research methods for business students (5th ed). Prentice Hall.

Sekaran, U. (2010) Research Methods for Business: A Skill-Building Approach (5th ed). John Wiley \& Sons, New York.

Shariah Governance Framework (SGF). (2011). Retrieved from https://www.bnm.gov.my/guidelines/05_shariah/02_Shariah_Governance_Framewor k_20101026.pdf

Sidani, Y. M. (2007). The audit expectation gap: evidence from Lebanon. Managerial Auditing Journal, 22(3), 288-302. https:// doi.org/10.1108/02686900710733152

Souiden, N. \& Rani, M. (2015). Consumer attitudes and purchase intentions toward Islamic banks: the influence of religiosity. International Journal of Bank Marketing, 33(2), 143-161. https:// doi.org/10.1108/IJBM-10-2013-0115

Sulaiman, M. (2001). Testing a model of Islamic corporate financial reports: some experimental evidence. International Journal of Economics, Management and Accounting, 9(2). 115-139.

Trauth, E. M., Farwell, D.W. \& Lee, D. (1993). The IS expectation gap: Industry expectations versus academic preparation. MIS Quarterly, 17(3), 47-72. https:/ / doi.org/10.2307/249773 


\section{Appendices}

\section{Appendix 1: Questionnaire for Shariah Practitioners}

\section{SECTION A: SHARIAH INFORMATION}

The objective of financial reporting is to provide useful Shariah information for decision making. Based on your expertise, please provide your opinion to what extent the following information is important to be disclosed in Islamic Bank's annual report.

Instruction: Please indicate your level of agreement on the importance of Shariah information by circling the appropriate number on a 5-point Likert scale as below:

$\begin{array}{lllll}1 & 2 & 3 & 4 & 5 \\ \text { Not important at } & \begin{array}{l}\text { Very minimal } \\ \text { all }\end{array} & \begin{array}{l}\text { Somewhat } \\ \text { impoterial or }\end{array} & \text { Important } & \begin{array}{l}\text { Extremely } \\ \text { important }\end{array} \\ & \begin{array}{l}\text { imporible in } \\ \text { importance) }\end{array} & & & \end{array}$

\begin{tabular}{|c|c|c|c|c|c|}
\hline \multirow{2}{*}{$\begin{array}{l}\text { Financing, Deposit and Investment } \\
\text { Types of financing (home, personal financing, etc) offered by the } \\
\text { bank }\end{array}$} & \multicolumn{3}{|c|}{$\begin{array}{l}\text { Not important } \\
\text { at all }\end{array}$} & \multicolumn{2}{|c|}{$\begin{array}{l}\text { Extremely } \\
\text { Important }\end{array}$} \\
\hline & 1 & 2 & 3 & 4 & 5 \\
\hline $\begin{array}{l}\text { Classification of financing into main Shariah contracts (BBA, } \\
\text { murabahah, etc) }\end{array}$ & 1 & 2 & 3 & 4 & 5 \\
\hline Ta'widh (compensation) charges for late payment financing & 1 & 2 & 3 & 4 & 5 \\
\hline Gharamah (penalty) charges for late payment financing & 1 & 2 & 3 & 4 & 5 \\
\hline Type of Islamic deposit (saving, demand, etc) & 1 & 2 & 3 & 4 & 5 \\
\hline $\begin{array}{l}\text { Classification of Islamic deposits into main Shariah contract } \\
\text { (wadi'ah, tawarruq) }\end{array}$ & 1 & 2 & 3 & 4 & 5 \\
\hline Opening and closing balance of restricted investment & 1 & 2 & 3 & 4 & 5 \\
\hline Sources of unrestricted investment account & 1 & 2 & 3 & 4 & 5 \\
\hline $\begin{array}{l}\text { Classification of unrestricted investment account into main Shariah } \\
\text { contract }\end{array}$ & 1 & 2 & 3 & 4 & 5 \\
\hline Profit sharing ratio of unrestricted investment account & 1 & 2 & 3 & 4 & 5 \\
\hline Method used to allocate investment profit (separate vs pooling) & 1 & 2 & 3 & 4 & 5 \\
\hline Zakat and Charity Fund & \multicolumn{3}{|c|}{$\begin{array}{l}\text { Not important } \\
\text { at all }\end{array}$} & \multicolumn{2}{|c|}{$\begin{array}{l}\text { Extremely } \\
\text { Important }\end{array}$} \\
\hline Opening and closing balance of zakat fund & 1 & 2 & 3 & 4 & 5 \\
\hline Amount of zakat payable & 1 & 2 & 3 & 4 & 5 \\
\hline Amount of zakat distributed & 1 & 2 & 3 & 4 & 5 \\
\hline Bank's responsibility to pay zakat & 1 & 2 & 3 & 4 & 5 \\
\hline Method applied in determining zakat base & 1 & 2 & 3 & 4 & 5 \\
\hline Beneficiaries of zakat fund & 1 & 2 & 3 & 4 & 5 \\
\hline Reason for Islamic bank not paying zakat & 1 & 2 & 3 & 4 & 5 \\
\hline Sources of donations / charities fund & 1 & 2 & 3 & 4 & 5 \\
\hline Usage of donations / charities fund & 1 & 2 & 3 & 4 & 5 \\
\hline Non- Shariah Compliance Activity & \multicolumn{3}{|c|}{$\begin{array}{l}\text { Not important } \\
\text { at all }\end{array}$} & \multicolumn{2}{|c|}{$\begin{array}{l}\text { Extremely } \\
\text { Important }\end{array}$} \\
\hline Nature of non-Shariah compliance activity & 1 & 2 & 3 & 4 & 5 \\
\hline Amount of non-Shariah compliance income & 1 & 2 & 3 & 4 & 5 \\
\hline $\begin{array}{l}\text { Number of non-Shariah compliance activities which occurred } \\
\text { during the year }\end{array}$ & 1 & 2 & 3 & 4 & 5 \\
\hline Rectification process to avoid recurrence & 1 & 2 & 3 & 4 & 5 \\
\hline Control measure to avoid recurrence & 1 & 2 & 3 & 4 & 5 \\
\hline Disposal of prohibited earnings to charitable causes & 1 & 2 & 3 & 4 & 5 \\
\hline
\end{tabular}




\begin{tabular}{lccccc}
\hline Shariah Committee & \multicolumn{2}{c}{$\begin{array}{c}\text { Not important } \\
\text { at all }\end{array}$} & \multicolumn{2}{c}{$\begin{array}{c}\text { Extremely } \\
\text { Important }\end{array}$} \\
\hline $\begin{array}{l}\text { Shariah committee member's signature on Shariah Committee } \\
\text { report }\end{array}$ & 1 & 2 & 3 & 4 & 5 \\
Purpose of Shariah committee engagement & 1 & 2 & 3 & 4 & 5 \\
Nature of work performed by Shariah committee & 1 & 2 & 3 & 4 & 5 \\
Management responsibility on ensuring Shariah compliance & 1 & 2 & 3 & 4 & 5 \\
Shariah committee's endorsement on Shariah compliance in & 1 & 2 & 3 & 4 & 5 \\
contract and document & & & & & \\
Shariah committee member's remuneration & 1 & 2 & 3 & 4 & 5 \\
Shariah committee member's qualification & 1 & 2 & 3 & 4 & 5 \\
\hline Qard & Not important & Extremely \\
& at all & & \multicolumn{2}{c}{ Important } \\
\hline Opening and closing balance of qard & 1 & 2 & 3 & 4 & 5 \\
Sources of qard fund & 1 & 2 & 3 & 4 & 5 \\
Usage of qard fund & 1 & 2 & 3 & 4 & 5 \\
\hline
\end{tabular}

Please provide your opinion in the allocated space:

What other Shariah disclosure items do you think is important? Kindly list it out below:

\section{SECTION B: DEMOGRAPHIC PROFILE}

Please tick $(\sqrt{ })$ or answer correspondingly on the items provided below.

1. Age (years)

30-35

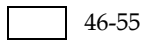

Above 55

2. Highest Education Level

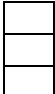

Diploma/Matriculation/A-Level

Bachelor's Degree

Master's Degree

$\mathrm{PhD}$

Others (please specify):

3. Working Experience in Islamic banking (in years)

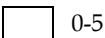

$0-5$

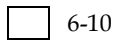

6-10

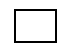

11-15

More than 15

4. Job position in the bank

Finance Officers

Shariah Officers

Shariah Committee

Please leave your contact number or email if you wish to participate further in an interview session:

\section{END OF QUESTIONNAIRE}

Please ensure that you have completed all the questions in this questionnaire. Thank you for your time and cooperation. 
Shariah disclosure expectation gap between Shariah practitioners and Islamic banks' customers...

Appendix 2: Questionnaire for Islamic Banks' Customers

\section{SECTION A: SHARIAH INFORMATION}

The questionnaire to the Islamic banks' customers is identical to the one sent to the Shariah Practitioners (as Appendix 1)

\section{SECTION B: DEMOGRAPHIC PROFILE}

Please tick $(\sqrt{ })$ or answer correspondingly on the items provided below.

1. Age (years)

30-35

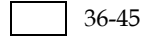

$\square$ 46-55

Above 55

2. Highest Education Level

Diploma/Matriculation/A-Level

Bachelor's Degree

Master's Degree

$\mathrm{PhD}$

Others (please specify):

3. Occupational

Lecturer

Islamic Accounting student

\section{END OF QUESTIONNAIRE}

Please ensure that you have completed all the questions in this questionnaire. Thank you for your time and cooperation. 